\title{
Isolation of polysaccharides from Plantago ovata and their evaluation as potential matrices for designing the controlled release floats of Piroxicam
}

\author{
Abdul Karim*, Tahir Mehmood and Muhammad Ashraf Shaheen \\ Department of Chemistry, University of Sargodha, Sargodha 40100-Pakistan \\ *Corresponding author's email: : karimiq65@gmail.com \\ Citation \\ Abdul Karim, Tahir Mehmood and Muhammad Ashraf Shaheen. Isolation of polysaccharides from Plantago Ovata \\ and their evaluation as potential matrices for designing the controlled release floats of Piroxicam. Pure and Applied \\ Biology. Vol. 5, Issue 4, pp1026-1043. http://dx.doi.org/10.19045/bspab.2016.50128
}

Received: 24/08/2016 Revised: 07/09/2016 Accepted: 12/09/2016

Online First: 17/09/2016

\section{Abstract}

The present study deals with isolation of different polysaccharides from Plantago Ovata husk and their use in designing the controlled release Gastro-Retentive (GR) floats of piroxicam (PRC). Gastroretentive floats are actually drug release (DR) moieties of low density used to retain the drug in stomach for maximum time to increase its bioavailability. The polysaccharides extracted from $P$. Ovata were selected due to its therapeutic impacts and ease in accessibility although synthetic polymers have already been utilized for designing such types of floats. The floats of that fraction were selected for designing further formulations having least lag time with maximum drug release retarding ability. For modifying the drug release (DR) rate; flax seed gel, gum tragacanth and Stearic acid were used as variables. The direct compression technique was used for compression and floats were characterized for uniformity in weight, drug content, friability and in vitro buoyancy. All fractions were characterized by FTIR, TGA, GPC and SEM study to find the nature of polysaccharide, predicting its stability and compatibility with human body. Some mathematical tools i.e. kinetic study and regression analysis (RA) were applied to find the effect of different variables on DR rate and closeness among the theoretical and experimental DR profile. The ethanol separated part (ENa) was seen to be most suitable in view of its better swelling ability and minimum lag time. The formulation $\mathrm{S}_{4} \mathrm{~F}_{9}$ was seem to be best fitted due to its minimum lag time, best drug entrapping ability and best suitability to Higuchi's model $\left(\mathrm{R}^{2}=0.957\right)$ and Power law $\left(\mathrm{R}^{2}=0.963\right)$. The $\mathrm{DR}$ mechanism was found to be nonFickian diffusion $(\mathrm{n}>0.45)$.

Keywords: Polysaccharide Gels; GR floats; GPC; FTIR; TGA; $3^{2}$ Factorial design; Lag time

\section{Introduction}

The regular polysaccharides and their derivatives are richly utilized as a part of pharmaceutical formulations of various types where they assume an imperative part as binder, film formers, DR modifiers, viscosity enhancers, stabilizers and suspending agents [1]. In a few cases, proteins, starches and plants hydro-gels are being used as a medium in CDDS (control 
drug delivery system) but most of polymers used have no therapeutic importance. Presently an exceptional consideration is being paid on selection of polymers having double characters i.e. restorative significance alongside DR retardant. The Plantago Ovata is an herbal plant and generally used as a drug for treating unending ailments i.e. coronary heart diseases, reducing the blood glucose level in blood.

In this study, focus is towards the segregation of new swellable biopolymer from $P$. Ovata husk and their utilization as matricing agent for designing the gastroretentive floats. The GR floats are actually floating drug tablets used for increasing the gastric residence time to increase the drug bioavailability. The swelling property of husk gel is reported in literature but its fractionation and then their use in CDDS is under progress [2]. It is most suitable than other synthetics gels due to being non-toxic, minimal effort of extraction, simplicity of accessibility, high partiality for water. It is water insoluble and mechanical activity of nutritious trench can't absorb it. There are so many mechanisms for controlling the DR and one such mechanism is swelling through hydration which is apparently present in P. Ovata seed husk. Swelling increases the pore volume of hydrogel and permits the dispersion of gastric medium for discharging the absorbed medicine in gel and thermal study reveals that it can face the environmental changes due to its stability at room temperature [37].

The PRC is a viable NSAID drug utilized for the treatment of joint inflammation [8]. Its typical dose is $20 \mathrm{mg}$ yet some time two fold doses are required to keep up the drug plasma level. The half-life of drug is around $40 \mathrm{~h}$ in man and is metabolized into dynamic metabolites and peak plasma level is achieved after $2 \mathrm{~h}$ subsequent to taking single dosage and it stayed dynamic over next $48 \mathrm{~h}$ because of expanded plasma halflife. The drug has exceptionally protein binding capacity and in this way it replaces numerous different types of drugs that are only limited to proteins. The present study was directed to prepare PRC floats utilizing $P$. Ovata seed husk and some other characteristic polysaccharides as DR modifier and was compared to sustained release marketed tablets $[9,10]$. This drug is utilized to assuage the joint inflammation. It works by preventing the production of some chemicals (prostaglandins) which are involved in mediation of pains in stiffness, swelling, tenderness and provocative conditions in joint inflammation [11-13].

The goal was to prepare GR floats of PRC. These extracted fractions meet all the physiological prerequisites required for matrix utilized for preparing the gastroretentive controlled release tablets i.e. being insoluble in water, having low density, high swelling/ re-swelling ability. By adjusting the matricing variables, the DR mechanism can be adjusted. The data acquired for in vitro DR were fitted to firstorder, zero-order, Higuchi model and Power law [14]. The Statistical method [MANOVA: multivariate analysis of variance] was used to analysis the DR data at different time intervals $[15,16]$. The highest value of regression coefficient $\left(\mathrm{R}^{2}\right)$ for Higuchi's model indicates that diffusion is predominant mechanism for controlling the release of drug. The main target was to increase the bioavailability by increasing its gastric residence time. All floats were tested for lag time, DR percentage, similarity and difference factors to find the optimum formulation $[17,18]$.

\section{Materials and methods}

The psyllium seed husk $(\mathrm{H})$, flax seed gel (FSG), gum tragacanth (GT) from local market and PRC was gifted from a pharmaceutical industry. Different 
chemicals: $\mathrm{C}_{2} \mathrm{H}_{5} \mathrm{OH}, \mathrm{CH}_{3} \mathrm{OH}, \mathrm{CH}_{3} \mathrm{COOH}$, Magnesium stearate from Merck and $\mathrm{HCl}$, $\mathrm{NaHCO}_{3}, \mathrm{NaOH}, \mathrm{CHCl}_{3}$, and $\left(\mathrm{CH}_{3}\right)_{2} \mathrm{CO}$ from ICI Ltd and Sigma-Aldrich. The double distilled water from distillation unit. The apparatus: Dissolution apparatus, UV/Vis Spectrophotometer (Shimadzu 2100, Tokyo, Japan), CHNS analyzer, FTIR spectrophotometer (IR Prestige-21 Shimadzu, Japan) from High Tech Lab University of Sargodha. All chemicals were used without further purification.

\section{Isolation of gel}

The $P$. Ovata husk gel $(\mathrm{H})$ was separated according to a published technique with some modifications $[19,20]$. The $P$. Ovata husk around $100 \mathrm{~g}$ was mixed in $1 \mathrm{~L}$ distilled water and was kept for $24 \mathrm{~h}$ for swelling. After complete swelling, whole mass was dissolved in $0.4 \mathrm{M} \mathrm{NaOH}$ solution by stirring with glass rod. To remove any insoluble material, the solution was filtered and to the filtrate; different organic solvents (Figure 1) were added separately in different portion of filtrate to coagulate the different insoluble fractions from filtrate. The isolated gels were dialyzed, dried and finely ground to fine powder. The fine powder was used as matricing agent for drug to design GR floats. The citrus acid and $\mathrm{NaHCO}_{3}$ was mixed in matrix to reduce the LT (The time after which tablets start floating on the dissolution medium) and increase the gastric retention time for increasing the bioavailability of drug.

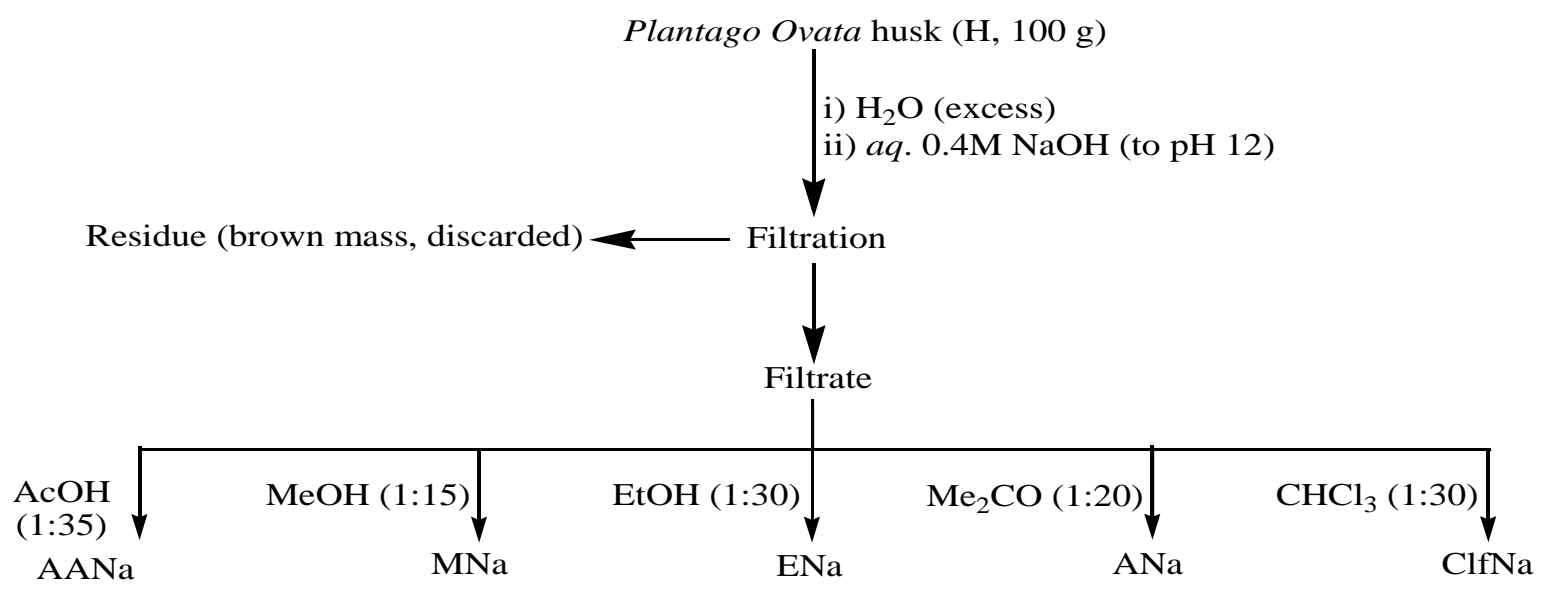

Acetic acid $=\mathrm{AcOH}$, Methanol $=\mathrm{MeOH}$, Ethanol $=\mathrm{EtOH}$, Acetone $=\mathrm{Me}_{2} \mathrm{CO}$, Chloroform $=\mathrm{CHCl}_{3}$ Gel extracted with $\mathrm{NaOH}$ and $\left[\mathrm{AcOH}(\mathrm{AANa}), \mathrm{MeOH}(\mathrm{MNa}), \mathrm{EtOH}(\mathrm{ENa}), \mathrm{Me}_{2} \mathrm{CO}(\mathrm{ANa}), \mathrm{CHCl}_{3}\left(\mathrm{ClfNa}^{\mathrm{A}}\right)\right]$

Figure 1. Extraction of different fractions from raw gel of P. Ovata

\section{Characterization of gels (Instrumentations)} Elemental analysis

The CHNS analyzer was used for elemental analysis of all samples and their results were reported.

\section{FT-IR}

The spectrometer (IR Prestige-21 Shimadzu, Japan) was used to get the spectra of all hydrogels sample using pellet $\mathrm{KBr}$ technique. After drying the samples under vacuum for $20 \mathrm{~h}$ were heated at $60{ }^{\circ} \mathrm{C}$ and then these samples were ground to fine mass. Pellets were compressed by applying pressure $60 \mathrm{kN}$.

\section{Thermal analysis (TA)}

The thermal analysis was conducted by thermal analyzer (SDT, Q-600, TA USA) under $\mathrm{N}_{2}$ atmosphere keeping heating rate $10^{\circ} \mathrm{C}, 15^{\circ} \mathrm{C}$ and $20^{\circ} \mathrm{C} \mathrm{min}{ }^{-1}$ ranging from room temp to $600^{\circ} \mathrm{C}$ in $\mathrm{Pt}$ crucible to find 
the thermal stability, degradation pattern, heat flow, activation temp and glass transition temp. The major degradation pattern was determined by pre-exponential factor (A) using Broido's method (Broido, 1969) and for calculating activation energy (Ea) Eq. 1 was used.

$\operatorname{Ln}[\ln (1 / y)]=-\mathrm{Ea} / \mathrm{RT}+\ln \mathrm{ART}^{2} \mathrm{~m} / \mathrm{Ea}(\mathrm{Eq} .1)$

It can be rearranged as,

$\ln \ln (1 / \mathrm{y})=-\left(\mathrm{E}_{\mathrm{a}} / \mathrm{R}\right)(1 / \mathrm{T})+\mathrm{constant}$

$\mathrm{y}$ is equal to $\left(\mathrm{w}_{\mathrm{t}}-\mathrm{w}_{\mathrm{f}}\right) /\left(\mathrm{w}_{0}-\mathrm{w}_{\mathrm{f}}\right), \mathrm{w}_{\mathrm{t}}$ was the mass of sample at time $\mathrm{t}, \mathrm{w}_{0}$ is initial mass and $\mathrm{w}_{\mathrm{f}}$ is final mass, where $\theta$ is heating rate and $\mathrm{R}$ is gas constant while $\mathrm{Tm}$ is the maximum reaction rate temp.

By plotting a graph between 1/T against $\ln \ln$ $(1 / y)$, a straight line is obtained and its slope and intercept gives $\mathrm{Ea}$ and $\mathrm{A}$ respectively. By single heating rate method, the kinetic parameters have been calculated but multiple effects heating rate method is most suitable [17]. The Doyle's method was used to find comprehensive index of intrinsic thermal stability (ITS), integral procedural decomposition temperature (IPDT) and thermal stability of samples [21- 23]. To find the energy of activation $\left(\Delta \mathrm{G}^{*}\right)$, enthalpy of activation $\left(\Delta \mathrm{H}^{*}\right)$ and entropy of activation $\left(\Delta S^{*}\right)$, the following standard equation was used

$$
\mathrm{E}_{\mathrm{a}}=-(\text { slope } \times 8.314)
$$

For data analysis, Universal Analysis 2000 software, version 4.2E, TA Instruments, USA and MS Excel® 2010 was used.

\section{Gel permeation chromatography (GPC)}

GPC technique was used to determine the GPC parameters i.e. molar masses of all fractions. The $M_{n}=$ average molar mass based on number of molecules $\mathrm{N}_{\mathrm{i}}$ in a particular weight class $\mathrm{M}_{\mathrm{i}}$.

$$
\mathrm{M}_{\mathrm{n}}=\sum \mathrm{N}_{\mathrm{i}} \mathrm{M}_{\mathrm{i}} / \sum \mathrm{N}_{\mathrm{i}} \quad \text { (Eq. 1) }
$$

$\mathrm{M}_{\mathrm{w}}=$ average molar mass based on weight fraction of molecules $\mathrm{W}_{\mathrm{i}}$ in a particular weight class $\left(\mathrm{M}_{\mathrm{i}}\right)$;

$$
\mathrm{M}_{\mathrm{w}}=\sum \mathrm{N}_{\mathrm{i}} \mathrm{M}_{\mathrm{i}}^{2} / \sum \mathrm{N}_{\mathrm{i}} \mathrm{M}_{\mathrm{i}} \text { (Eq. 2) }
$$

Where $\mathrm{Mz}=\sum \mathrm{N}_{\mathrm{i}} \mathrm{M}_{\mathrm{i}}^{3} / \sum \mathrm{N}_{\mathrm{i}} \mathrm{M}_{\mathrm{i}}^{2}$ (Eq. 3)
From ratio of different average molar masses, the polydispersity index (PDI) was calculated (Eq. 4)

$$
\mathrm{PDI}=\mathrm{M}_{\mathrm{w}} / \mathrm{M}_{\mathrm{n}} \text { (Eq. 4) }
$$

For GPC analysis, pullulan and dextran were used as standard (Polymer Standards Service, Germany). Dimethyl sulphoxide was used as eluent in a system that is fitted with two columns functioning at run rate 0.5 $\mathrm{mL} \min ^{-1}$ at $70^{\circ} \mathrm{C}$ using volume $50 \mu \mathrm{L}$ as injection.

\section{SEM studies}

The pellets of all fractions were compressed at hydraulic press at pressure 3000 Psi mounted with Ag-painted aluminum stubs coated with $\mathrm{Au}$ working at accelerating voltage $10 \mathrm{kV}$. Different micrographs were taken at different magnifications to study the surface morphology. Greater the roughness on surface, greater is the adsorption power of gel to adsorb and uneven surface has greater absorption tendency. The drug release behavior of $\mathrm{ENa}$ was matching with the set criteria (minimum lag time), therefore other fractions were ignored. Moreover it was found that different fractions have different drug release behavior with different drugs. The ENa fraction was best fitted therefore was selected as a standard for designing the desired drug release floats and therefore its GPC chromatogram was inserted.

\section{Calibration curve}

A stock solution of PRC $(10 \mathrm{mg} / 100 \mathrm{~mL})$ was prepared in simulated gastric fluid (SGF) [pH $1.2 \mathrm{HCl}(5 \mathrm{~mL} \mathrm{HCl}$ concentrated in $991.5 \mathrm{~mL}$ distilled water) with purified pepsin]. The prepared samples were diluted 10 times and diluted medium was further diluted to $50 \%$ to obtain a solution of known concentration solutions ranging from $0.5-$ $2.5 \mu \mathrm{g} / \mathrm{m}$ L. The absorbance was measured spectro-photometrically at $234 \mathrm{~nm}$ with the mean data $(n=5)$. The calibration graph for PRC (Figure 2a) was plotted against its concentration and was regressed into linear 
line. The concentration of DR was calculated using equation

$$
\mathrm{y}=0.070 \mathrm{X}+0.004
$$

The calibration graph (Figure $2 b$ ) and DR profile of all fractions (Figure 3, Table 1) are shown. In equation, $\mathrm{y}$ is $\mathrm{DR} \%, \mathrm{X}$ is the<smiles>CN1C(C(=O)Nc2ccccn2)=C(O)c2ccccc2S1(=O)=O</smiles>

amount of drug released. By putting the value of other variables, we can calculate the value of $\mathrm{X}$ during that interval. This plot is drawn using DR data taken from pure drug only without any matrix.

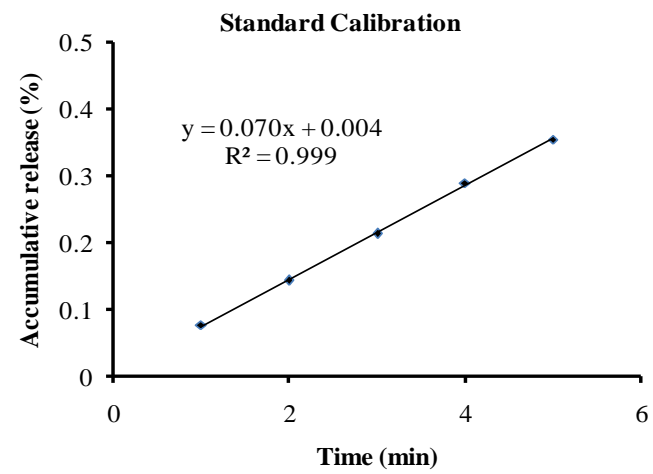

Figure 2. a, Structure of PRC (L) b, Calibration curve for PRC (R)
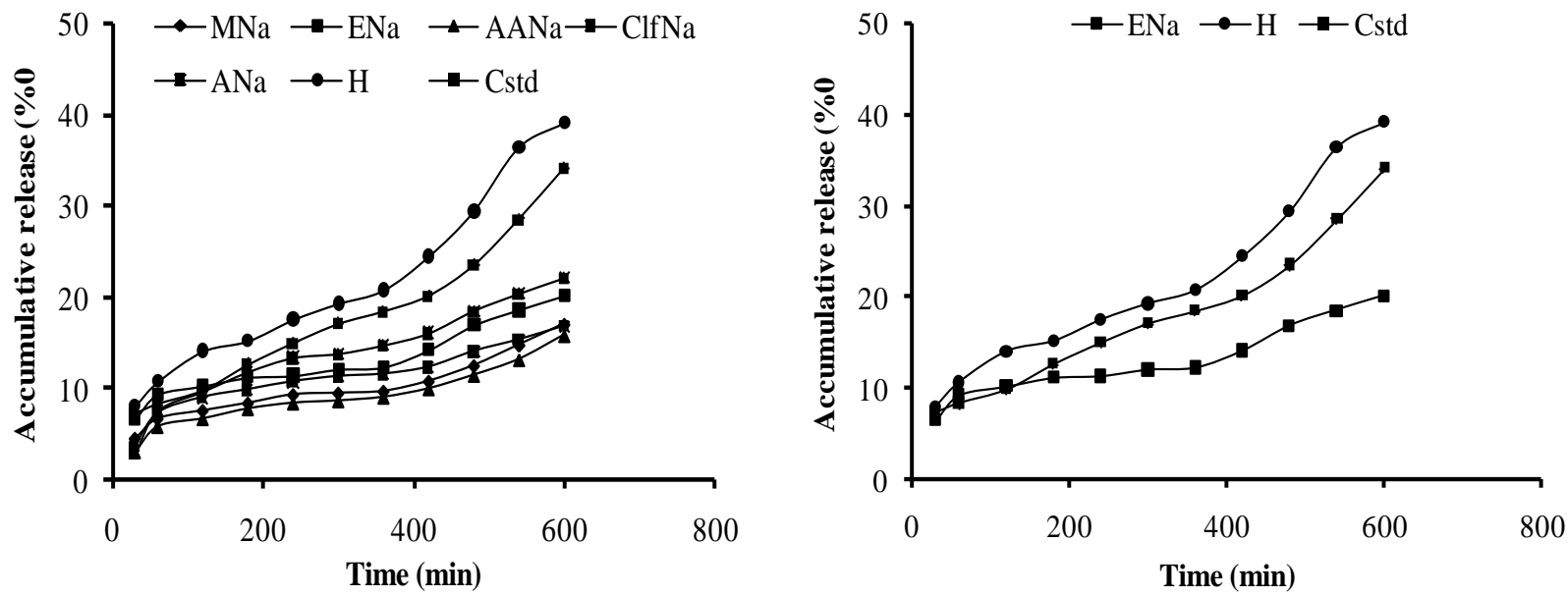

Figure 3. (R) A plot of \% release of drug from all hydrogels (L) The \% release of drug from ENa matrix float, $\mathrm{H}_{\text {matrix }}$ and $\mathrm{C}_{\text {std. }} v \mathrm{~s}$ time for $10 \mathrm{~h}$ (Table 2)

Table 1. Comparative DR \% from isolated fractions $V S$ lag time

\begin{tabular}{|c|l|l|l|l|l|l|l|}
\hline PRC & \multicolumn{1}{|c|}{ MNa } & \multicolumn{1}{|c|}{ ENa } & \multicolumn{1}{|c|}{ AANa } & \multicolumn{1}{|c|}{ ClfNa } & \multicolumn{1}{|c|}{ ANa } & \multicolumn{1}{c|}{ H } & \multicolumn{1}{c|}{ Cstd } \\
\hline Rel\% & 9.0 & 21.1 & 16.9 & 16.9 & 24.1 & 43.9 & 35.2 \\
\hline LT (min) & 42 & 15 & 40 & 35 & 42 & 48 & 32 \\
\hline
\end{tabular}

*Fractions extracted from hydrogel solution of $\mathrm{NaOH}$ using solvents, $\mathrm{MNa}=$ Methanol, $\mathrm{ENa}=\mathrm{Ethanol}, \mathrm{AANa}=$ acetic acid, $\mathrm{Clf} \mathrm{Na}=$ chloroform, $\mathrm{ANa}=$ acetone, $\mathrm{H}=$ whole gel and $\mathrm{Cstd}=$ standard tablet

The floats prepared using ENa showed minimum LT, therefore ENa was selected as matricing agent for further study. Although
DR from all fractions was generally less than required for achieving effective drug blood plasma level. Further formulations 
were designed to find optimized formulation. Different batches were prepared with different amounts of excipients using $\mathrm{ENa}$ as major matricing agent to explore the most potential formulation.

\section{Preparation of matrix tablets}

The wet granulation technique was used to prepare the ENa floats. Excipients including drug were blended geometrically and formulations were designed as per factorial model (Table 2). For sorption of drug, ENa was put in clear drug solution for maximum swelling. After maximum swelling, the swelled lump was kept in long container having non-sticky surface fitted with pump. The whole mass was splashed through little opening on inner side of container fitted with heating heated at $45{ }^{0} \mathrm{C}$. The dried granules were collected and compacted in to floats under pressure of $10 \mathrm{kN}$ on single punch machine fitted with $9.5 \mathrm{~mm}$ flat punch. The $\mathrm{iPrOH}$ was added in blended material to homogenize the swelling rate and magnesium stearate was added as glident.

Table 2. Floats formulations of PRC (40 mg)

\begin{tabular}{|c|c|c|c|c|c|c|}
\hline Batch & Variables & Resources & Low (-1) & Medium (0) & High (+1) & Constant*(mg) \\
\hline \multirow{2}{*}{$1^{\text {st }}$} & $\mathrm{X}_{1}$ & $\mathrm{ENa}$ & 80 & 160 & 220 & $\mathrm{NaHCO}_{3}=10$ \\
\cline { 2 - 7 } & $\mathrm{X}_{2}$ & $\mathrm{SA}$ & 10 & 20 & 30 & $\mathrm{CA}=5$ \\
\hline \multirow{2}{*}{$2^{\text {nd }}$} & $\mathrm{X}_{1}$ & $\mathrm{ENa}$ & 80 & 160 & 220 & $\mathrm{NaHCO}_{3}=10$ \\
\cline { 2 - 7 } & $\mathrm{X}_{2}$ & $\mathrm{SA}$ & 5 & 10 & 15 & $\mathrm{CA}_{2} 5$ \\
\hline \multirow{2}{*}{$3^{\text {rd }}$} & $\mathrm{X}_{1}$ & $\mathrm{ENa}$ & 80 & 160 & 220 & $\mathrm{NaHCO}_{3}=5$ \\
\cline { 2 - 7 } & $\mathrm{X}_{2}$ & $\mathrm{FSG}$ & 5 & 10 & 15 & $\mathrm{CA}_{2} .5$ \\
\hline \multirow{2}{*}{$4^{\text {th }}$} & $\mathrm{X}_{1}$ & $\mathrm{ENa}$ & 80 & 160 & 220 & $\mathrm{NaHCO}_{3}=5$ \\
\cline { 2 - 7 } & $\mathrm{X}_{2}$ & $\mathrm{GT}$ & 5 & 10 & 15 & $\mathrm{CA}_{2} .5$ \\
\hline
\end{tabular}

${ }^{*} \mathrm{CHCl}_{3}=5 \mathrm{~mL},{ }^{i} \mathrm{PrOH}$ (isopropyl alcohol) $=2 \mathrm{~mL}$, Magnesium stearate $=5 \mathrm{mg}$ in each floats

Analysis of friability, drug content and stability study

Ten floats weigh equal to $100 \mathrm{mg}$ were transferred to $100 \mathrm{~mL}$ volumetric flask and subsequent to blending in solution of $\mathrm{pH}$ 1.2. The blend was filtered and $1 \mathrm{~mL}$ of filtrate was further diluted to form a solution $\left(100 \mu \mathrm{g} \mathrm{m} \mathrm{L}^{-1}\right)$. The analysis was conducted at $\lambda \max 234 \mathrm{~nm}$ using UV -Visible spectrophotometer. To test the friability, floats were kept in a drum rotating at a speed of $30 \mathrm{rpm} \mathrm{min}{ }^{-1}$ and sample was rotated at a speed 100 revolutions $\min ^{-1}$ for $5 \mathrm{~min}$ to find the disintegration of float. The floats were dusted off and were weighed again and \% loss in weight was calculated from equation.

Friability $=($ initial mass - final mass $) /$ initial mass $\times 100$

\section{Dissolution study}

The USP paddle dissolution apparatus- II was used to study the $\mathrm{DR}$ at $37^{\circ} \mathrm{C} \pm 0.1^{\circ} \mathrm{C}$ rotating at $50 \mathrm{rpm}$. The buffer $\mathrm{pH} 1.2$ was taken in each container $(900 \mathrm{~mL})$. After fixed time interval, $5 \mathrm{~mL}$ sample was taken out and was analyzed at double beam spectrophotometer (Schimadzu UV-1700) at $\lambda \max 234 \mathrm{~nm}$. After withdrawal of test sample, buffer medium kept at same temperature was added to have the volume $900 \mathrm{~mL}$. The DR \% was calculated from withdrawn sample.

\section{Statistical analysis}

The $3^{3}$ full factorial designs (Table 1) were used for RA (regression analysis) to determine the effect of independent variables on $\mathrm{DR} \%$. The statistical equation was derived to find the effect of all variables.

$S \%=\beta_{0}+\beta_{1} X_{1}+\beta_{2} X_{2}+\beta_{12} X_{1} X_{2}+\beta_{1} X_{1}^{2}$ $+\beta_{2} X_{1}^{2}$

Where $\mathrm{S} \%$ (DR \%); $\beta$ is coefficient of regression; $\mathrm{X}_{1}$ and $\mathrm{X}_{2}$ stands for effect of 
both independent variables; $\mathrm{X}_{1} \mathrm{X}_{2}$ is the interactions factor between $X_{1}$ and $X_{2}$ and $\mathrm{X}_{1}^{2}$ and $\mathrm{X}_{1}^{2}$ are quadratic terms.

\section{Result and discussion \\ Description of ENa \\ Elemental analysis}

Each sample was analyzed thrice. The percentage of Carbon was found to be lower $(40.2 \%)$ than in other natural polysaccharides $(45.0 \%)$ and Hydrogen content was greater $(6.5 \%)$ than observed in other polysaccharides $(6.0 \%)$ due to its better water upholding capability. The $\mathrm{N}$ was not detected in any sample showing that protein was absent in all sample.

\section{FT IR spectroscopy}

The FTIR spectrum of ENa (Figure 4) shows that following absorbance were indicated. The assignment at $3374-3443 \mathrm{~cm}^{-}$ ${ }^{1}$ was due to $-\mathrm{OH}$ stretching broad band and a peak at 2882-2918 $\mathrm{cm}^{-1}$ was due to saturated $\mathrm{C}-\mathrm{H}$ stretching and absorbance at $1563-1638 \mathrm{~cm}^{-1}$ was showing deformation by entrapped water, a neat band at 1014$1052 \mathrm{~cm}^{-1}$ was showing $\beta$ - glycosides linkage and band at $643-692 \mathrm{~cm}^{-1}$ and 529$550 \mathrm{~cm}^{-1}$ are indicating polymer backbone.

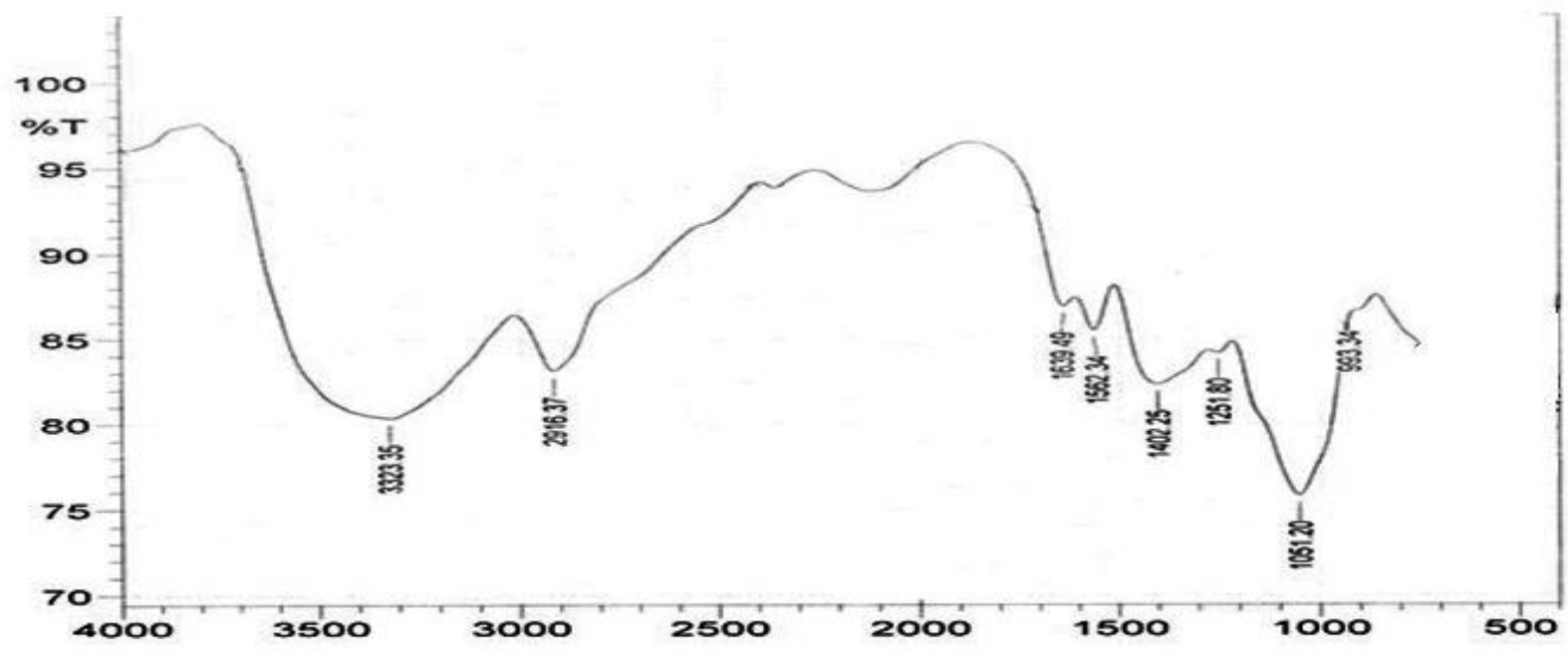

Figure 4. FTIR spectrum of ENa

\section{GPC study (comparative study)}

The molar mass distribution of all hydrogels was determined by GPC study (Table 2). The heterogeneity was determined from polydispersity index (PDI) that is the ratio of $M w$ and $M n$. The molar mass averages for a monodisperse polymer are almost equal and their PDI values are close to 1 . In a poly disperse system, $M_{z}>M_{w}>M_{n}$ as the result the PDI value is greater than 1. For all fractions, the molar mass distribution is shown (Table 3) and their PDI are found to be; $\mathrm{ANa}=2.87, \mathrm{AANa}=2.69, \mathrm{MNa}=3.16$, $\mathrm{ClfNa}=3.78$ and $\mathrm{ENa}=3.75$. From these values it was found that their heterogeneity index is ranging from 2.682 to 3.781 indicating that these hydrogels are showing poly disparity. 
Table 3. GPC parameters of hydrogel fractions

\begin{tabular}{|l|l|l|l|l|l|}
\hline Parameters & AANa & ANa & ENa & MNa & ClfNa \\
\hline $\mathbf{M n}\left(\mathbf{g ~ m o l}^{-1}\right)$ & $4.991 \times 10^{3}$ & $4.482 \times 10^{3}$ & $3.326 \times 10^{3}$ & $3.566 \times 10^{3}$ & $2.158 \times 10^{3}$ \\
\hline $\mathbf{M w}\left(\mathbf{g ~ m o l}^{-1}\right)$ & $1.327 \times 10^{4}$ & $1.265 \times 10^{4}$ & $1.353 \times 10^{4}$ & $1.124 \times 10^{4}$ & $8.167 \times 10^{3}$ \\
\hline $\mathbf{M z}\left(\mathbf{g ~ m o l}^{-1}\right)$ & $2.641 \times 10^{4}$ & $2.934 \times 10^{4}$ & $2.955 \times 10^{4}$ & $2.198 \times 10^{4}$ & $2.185 \times 10^{4}$ \\
\hline $\mathbf{M p}\left(\mathbf{g ~ m o l}^{-1}\right)$ & $7.372 \times 10^{3}$ & $8.473 \times 10^{3}$ & $8.252 \times 10^{3}$ & $1.597 \times 10^{4}$ & $4.142 \times 10^{3}$ \\
\hline Vp $\left(\mathbf{c m}^{\mathbf{3}}\right)$ & 7.445 & 7.366 & 7.397 & 7.089 & 7.715 \\
\hline PDI & 2.695 & 2.87 & 3.75 & 3.169 & 3.787 \\
\hline
\end{tabular}

\section{Scanning electron microscopy}

Different photographs were taken at different magnifying power to study the surface morphology. The SEM image of $\mathrm{ENa}$ is shown for representative purpose (Figure 5).

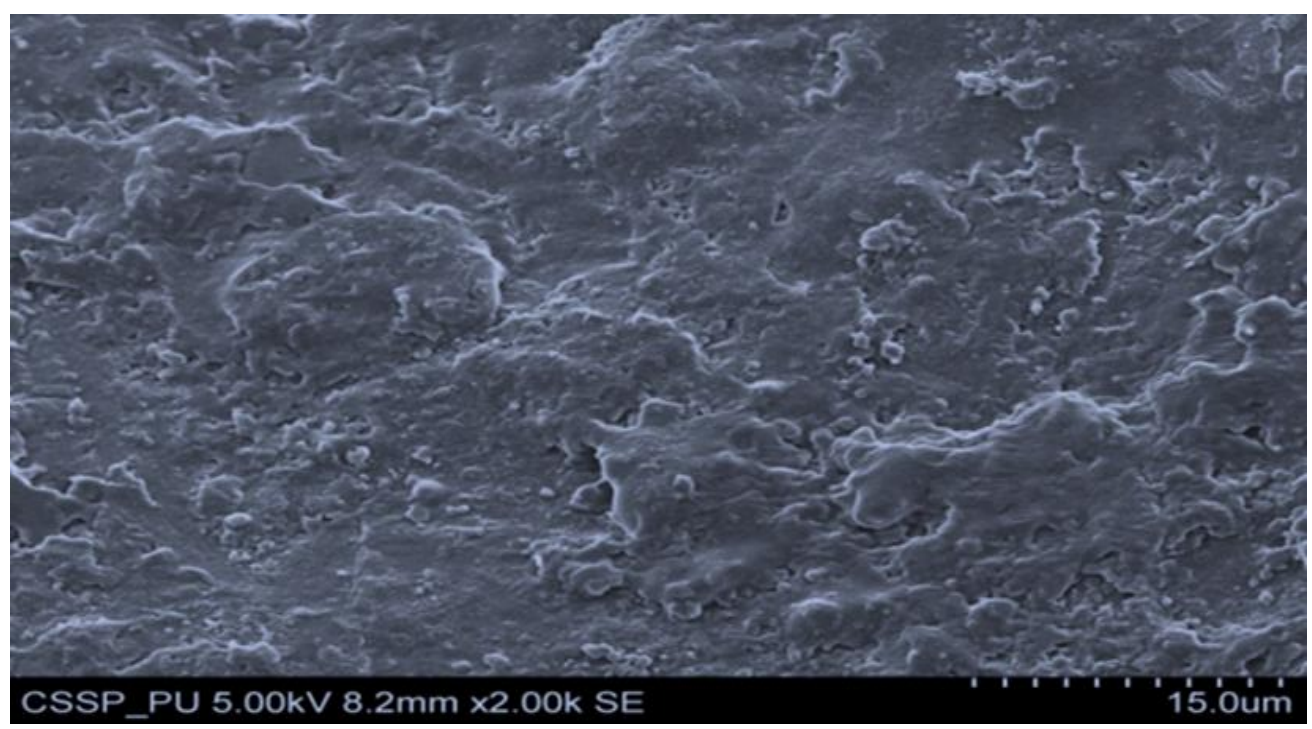

Figure 5. Scanning electron microscopy of ENa

\section{Thermal Analysis}

The thermal analysis was conducted for isolated fractions ranging from room temperature to $600^{\circ} \mathrm{C}$. An endothermic weight loss $(10-12 \%)$ was seen at 190$200^{\circ} \mathrm{C}$, might be due to loss of absorbed water [24]. The weight loss about $\sim 46 \%$ occurred in range of $226-328^{\circ} \mathrm{C}$ due to main decomposition of structure (Figure 5a, b). This step is an exothermic in nature. Another degradation with weight loss $25 \%$ was observed at $450-570^{\circ} \mathrm{C}$ might be due to complete decomposition of husk hydrogels to gaseous products $\left(\mathrm{CO}_{2}, \mathrm{CO}\right.$, and $\left.\mathrm{H}_{2} \mathrm{O}\right)$ leaving behind carbon content ash residue. No significant difference among thermal behavior of these fractions was seen. The average $E a$ values which were found to be $134 \mathrm{~kJ} \mathrm{~mol}^{-1}$ at multiple heating rates. Using the parameters like IPDT and ITS values (Doyle's method) the thermal stability of all fractions was assessed. The IPDT and ITS values were ranging from $275-305{ }^{\circ} \mathrm{C}$ and $0.43-0.490$ respectively. These values indicate that all fractions are fairly stable. FWO method was used to find the $E_{a}$ values for major stage of decomposition (Table 4). The FWO and $\alpha-T$ plots for ENa are shown in Figure 6. The multistep degradation pattern was apparent from variability in $E_{a}$ with $\alpha$. 

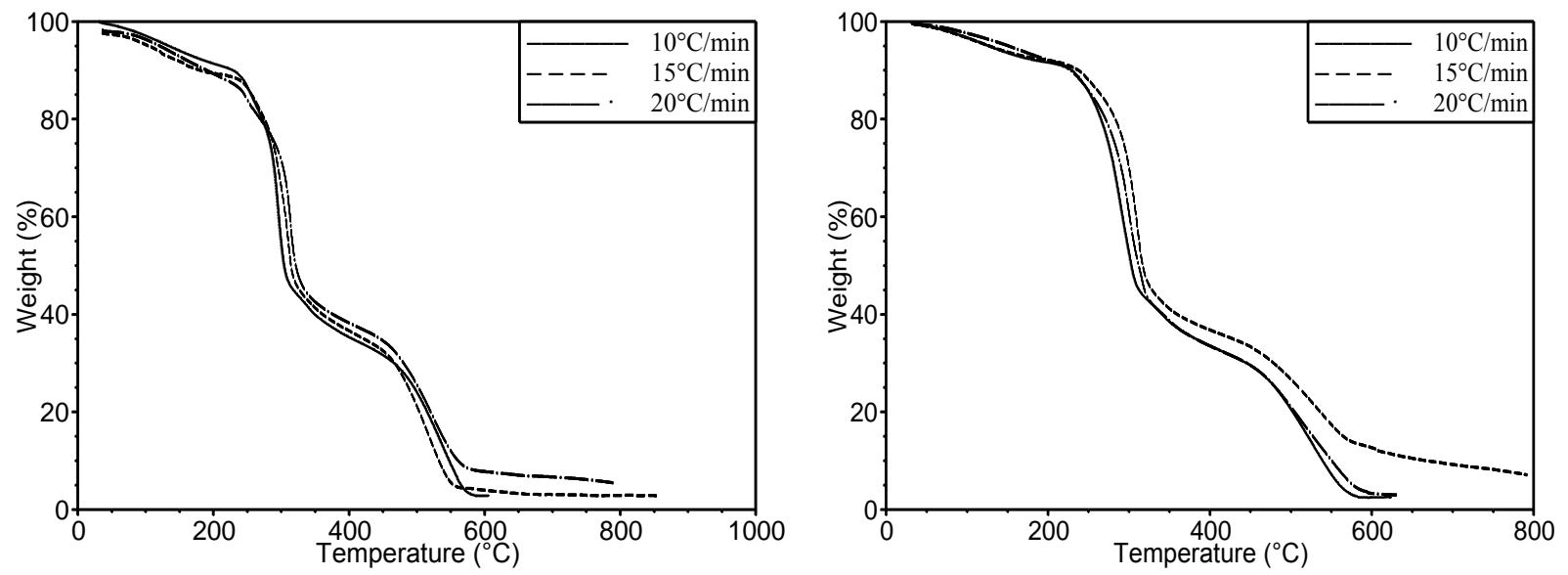

Figure 5 a, b. Thermal analysis of ENa and AANa $(L \rightarrow R)$
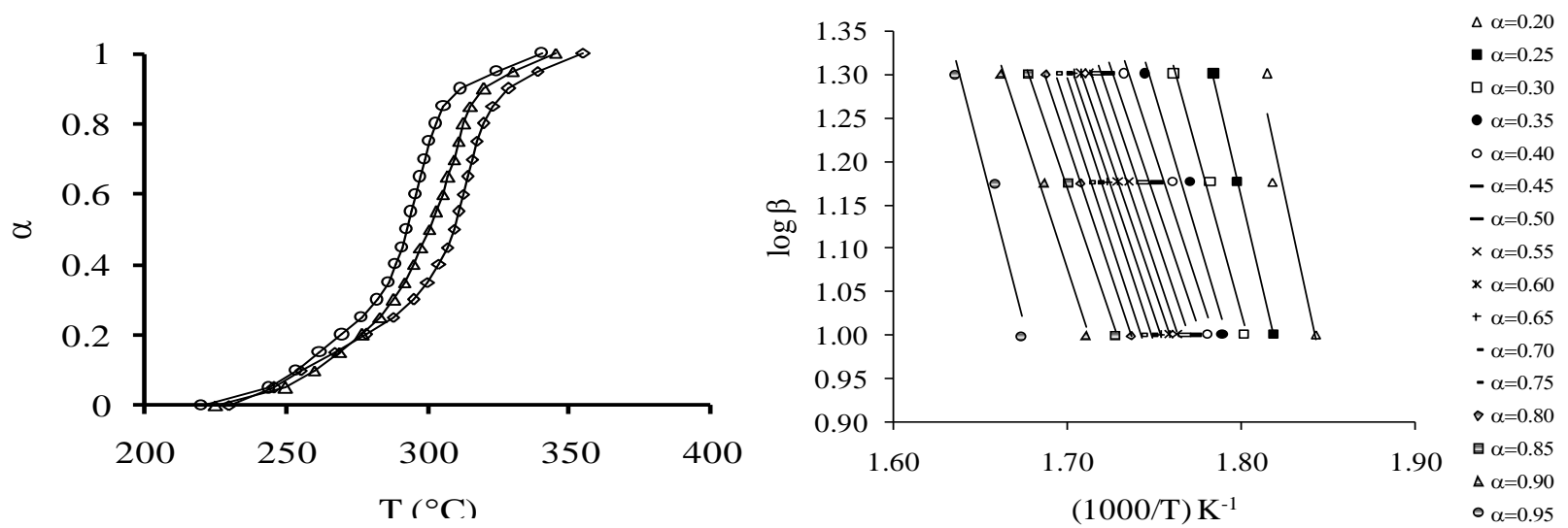

Figure 6. Representative $\alpha-T$ curve and $\log \beta$ for selected fraction

Table 4. Thermal study of Plantago Ovata husk fractions

\begin{tabular}{|c|c|c|c|c|c|c|c|c|c|c|}
\hline $\begin{array}{c}\text { Sample } \\
\text { code }\end{array}$ & $\begin{array}{l}\text { Temp. } \\
\text { range } \\
\left({ }^{\circ} \mathrm{C}\right)\end{array}$ & $\begin{array}{l}\text { weight } \\
\text { loss } \\
(\%)\end{array}$ & $\begin{array}{c}E_{a} \\
\mathrm{~kJ} \mathrm{~mol}^{-1}\end{array}$ & $\begin{array}{c}\Delta \mathbf{H}^{*} \\
\mathbf{k J} \mathbf{m o l}^{-1}\end{array}$ & $\begin{array}{c}\Delta \mathbf{S}^{*} \\
\mathrm{JK}^{-1} \mathbf{m o l}^{-1}\end{array}$ & $\begin{array}{c}\Delta \mathbf{G}^{*} \\
\mathbf{k J} \mathrm{mol}^{-1}\end{array}$ & $\ln A$ & $\begin{array}{c}\text { IPDT } \\
\left({ }^{\circ} \mathbf{C}\right)\end{array}$ & ITS & $\begin{array}{c}\text { weight at } \\
600{ }^{\circ} \mathrm{C} \\
(\%)\end{array}$ \\
\hline AANa & $250-32$ & 56.79 & 139.61 & 134.74 & -74.06 & 179.07 & 21.22 & 275.42 & 0.44 & 0.401 \\
\hline MNa & $230-31$ & 42.46 & 141.45 & 138.71 & -54.79 & 169.87 & 23.51 & 318.44 & 0.48 & 11.221 \\
\hline ENa & $230-33$ & 49.10 & 143.58 & 138.84 & -52.34 & 168.56 & 23.81 & 289.22 & 0.49 & 0.981 \\
\hline $\mathrm{ANa}$ & $255-32$ & 46.60 & 136.54 & 131.67 & -78.36 & 176.5 & 20.71 & 359.28 & 0.48 & 0.535 \\
\hline ClfNa & $245-32$ & 48.18 & 148.78 & 143.9 & -56.79 & 178.18 & 23.3 & 315.99 & 0.51 & 14.598 \\
\hline
\end{tabular}

\section{Isolation of gel fractions}

The relative amounts of hydrogels isolated from $P$. Ovata husk is,

AANa (60 percentage) $>\mathrm{ENa}(44 \%)>\mathrm{ClfNa}$ $(30 \%)>\mathrm{MNa}(50 \%)>\mathrm{ANa}(20 \%)$ (Figure 1).

\section{DR and in vitro buoyancy study}

All physical parameters i.e. content uniformity, thickness, weight variation (less than $\pm 5 \%$ ), floats size were found in acceptable limits (Table 5). 
Table 5. Physiochemical properties and floating lag time of floats of different fractions

\begin{tabular}{|c|c|c|c|c|}
\hline Tablet matrix & $\begin{array}{c}\text { Crushing } \\
\text { strength (kN) }\end{array}$ & $\begin{array}{c}\text { Content } \\
\text { uniformity (\%) }\end{array}$ & Friability (\%) & LT (min) \\
\hline MNa & $9.8 \pm 0.5$ & $97.5 \pm 0.5$ & 0.46 & 42 \\
\hline ENa & $9.7 \pm 0.5$ & $96.7 \pm 0.5$ & 0.35 & 15 \\
\hline AANa & $9.7 \pm 0.5$ & $98.9 \pm 0.5$ & 0.46 & 40 \\
\hline ANa & $9.4 \pm 0.5$ & $98.4 \pm 0.5$ & 0.48 & 42 \\
\hline ClfNa & $9.2 \pm 0.5$ & $96.4 \pm 0.5$ & 0.67 & 35 \\
\hline H & $9.4 \pm 0.5$ & $97.6 \pm 1.5$ & 0.68 & 48 \\
\hline Cstd & $9.3 \pm 0.5$ & $97.4 \pm 1.5$ & 0.49 & 32 \\
\hline
\end{tabular}

Due to best retarding ability of $\mathrm{ENa}$ for PRC, it was selected for designing the other formulations. The drug remained within the matrix was relatively greater, therefore new Formulations were designed by changing the amount of variables to increase the availability of drug. The design criteria was as; after $2 \mathrm{~h} ; 25 \pm 5 \%$, after $5 \mathrm{~h} ; 45 \pm 5 \%$ and after $10 \mathrm{~h} ; 65 \pm 5 \% .1^{\text {st }}$ batch could not meet the set criteria except $\mathrm{S}_{1} \mathrm{~F}_{9}$, therefore a $2^{\text {nd }}$ batch was designed where DR was also less than $25 \%$ in $2 \mathrm{~h}$ but after $5 \mathrm{~h}$ it was very close to stated criteria. After $10 \mathrm{~h}$, release rate was less than $65 \%$. Therefore this batch was also rejected. In $3^{\text {rd }}$ batch; the DR\% in 2 $\mathrm{h}$ and $5 \mathrm{~h}$ were very close to set target (> $25 \%,>45 \%$ ) but after $10 \mathrm{~h}$, it was again less than stated criteria. Therefore $4^{\text {th }}$ batch was designed by replacing TG by LG where $\mathrm{DR} \%$ was $>25 \%,>45 \%$ and $\approx 65 \%$ for $2 \mathrm{~h}$, $5 \mathrm{~h}$ and $10 \mathrm{~h}$ respectively (Table 6 ).

Table 6. DR of PRC at various interval

\begin{tabular}{|c|c|c|c|c|c|c|c|}
\hline Ist batch & $S 1_{2 h}$ & S1 $5 \mathrm{~h}$ & S1 $10 \mathrm{~h}$ & $2^{\text {nd }}$ batch & $\mathrm{S2}_{2 \mathrm{~h}}$ & $\mathrm{S2}_{5 \mathrm{~h}}$ & S2 $10 \mathrm{~h}$ \\
\hline F1 & 8.8 & 10.60 & 27.3 & F1 & 7.6 & 25.2 & 39.0 \\
\hline F2 & 12.5 & 16.2 & 30.0 & F2 & 8.5 & 27.0 & 42.9 \\
\hline F3 & 15.4 & 22.9 & 39.6 & F3 & 10.4 & 28.7 & 45.5 \\
\hline F4 & 7.2 & 8.51 & 26.1 & F4 & 8.5 & 25.0 & 36.2 \\
\hline F5 & 12.1 & 7.50 & 35.7 & F5 & 9.3 & 26.5 & 38.1 \\
\hline F6 & 15.9 & 11.10 & 42.0 & F6 & 10.0 & 27.7 & 41.2 \\
\hline F7 & 5.3 & 15.01 & 19.5 & F7 & 8.4 & 23.9 & 34.7 \\
\hline F8 & 10.7 & 18.10 & 35.1 & F8 & 10.9 & 17.7 & 37.3 \\
\hline F9 & 13.8 & 22.13 & 42.2 & F9 & 11.8 & 19.6 & 41.1 \\
\hline $3^{\text {rd }}$ batch & $\mathrm{S3}_{2 \mathrm{~h}}$ & $\mathrm{S3}_{5 \mathrm{~h}}$ & $\mathbf{S 3}_{10 \mathrm{~h}}$ & $4^{\text {th }}$ batch & S4 $2 h$ & S4 5h & S4 $10 \mathrm{~h}$ \\
\hline F1 & 27.6 & 43.5 & 24.2 & F1 & 28.9 & 46.2 & 51.6 \\
\hline F2 & 29.2 & 47.3 & 26.8 & F2 & 30.5 & 48.1 & 57.1 \\
\hline F3 & 30.9 & 48.7 & 28.1 & F3 & 31.4 & 42.5 & 63.0 \\
\hline F4 & 26.4 & 42.7 & 22.5 & F4 & 21.4 & 44.8 & 50.2 \\
\hline F5 & 27.5 & 44.8 & 24.7 & F5 & 30.3 & 48.3 & 62.5 \\
\hline F6 & 28.5 & 77.1 & 25.6 & F6 & 41.9 & 50.0 & 70.6 \\
\hline F7 & 22.1 & 41.8 & 22.6 & F7 & 24.5 & 34.1 & 48.1 \\
\hline F8 & 28.5 & 43.9 & 23.8 & F8 & 29.3 & 46.2 & 52.0 \\
\hline F9 & 33.7 & 46.5 & 24.2 & F9 & 32.1 & 52.1 & 67.9 \\
\hline
\end{tabular}


So this batch was found to favorable for designing the desired formulations. In $4^{\text {th }}$ batch, the formulation $\mathrm{S}_{4} \mathrm{~F}_{9}$ was found to be best fitted due to minimum LT (Table7) and maximum DR \% sufficient for achieving the drug plasma level (Figure 7).

Table 7. Lag time study of all batches

\begin{tabular}{|c|c|c|c|c|c|c|c|c|c|}
\hline Fractions & MNa & ENa & AANa & ClfNa & ANa & H & Cstd & & \\
\hline Time (min) & 42 & 15 & 40 & 35 & 40 & 38 & 25 & & \\
\hline $\mathbf{1}^{\text {st }} \mathbf{b a t c h}$ & F1 & F2 & F3 & F4 & F5 & F6 & F7 & F8 & F9 \\
\hline Time (S) & 140 & 85 & 65 & 150 & 120 & 90 & 175 & 155 & 100 \\
\hline $2^{\text {nd }}$ batch & F1 & F2 & F3 & F4 & F5 & F6 & F7 & F8 & F9 \\
\hline Time (S) & 140 & 125 & 100 & 160 & 145 & 120 & 180 & 150 & 100 \\
\hline $\mathbf{3}^{\text {rd }}$ batch & F1 & F2 & F3 & F4 & F5 & F6 & F7 & F8 & F9 \\
\hline Time (S) & 105 & 85 & 65 & 85 & 70 & 60 & 150 & 125 & 90 \\
\hline $\mathbf{4}^{\text {th }}$ batch & F1 & F2 & F3 & F4 & F5 & F6 & F7 & F8 & F9 \\
\hline Time (S) & 200 & 150 & 135 & 225 & 185 & 160 & 275 & 205 & 160 \\
\hline
\end{tabular}

\section{DR profiles of all batches}
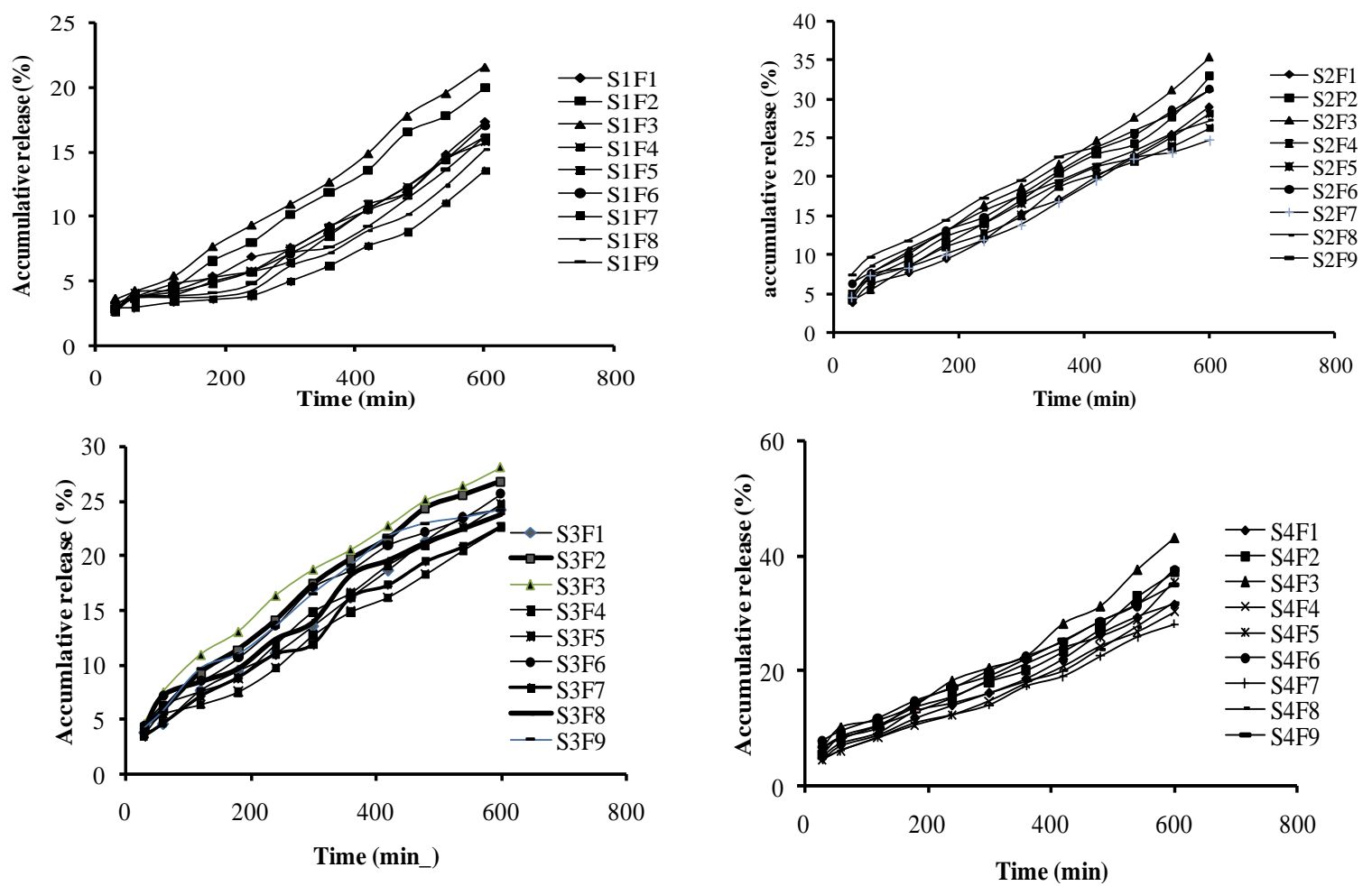

Figure 7. DR profiles of designed batche 
Table 8. Kinetic studies of $1^{\text {st }}$ batch

\begin{tabular}{|l|l|l|l|l|l|l|l|l|l|l|l|l|}
\hline \multicolumn{3}{|l|}{} & \multicolumn{2}{l}{ Z- Order } & \multicolumn{2}{l|}{ F-Order } & \multicolumn{2}{l|}{ H-Model } & \multicolumn{2}{l|}{ H-C Model } & \multicolumn{2}{l|}{ P- law } \\
\hline PRC & $\mathbf{S}_{\mathbf{1 0 h}(\%)}$ & $\mathbf{k}_{\mathbf{0}}$ & $\mathbf{R}^{\mathbf{2}}$ & $\mathbf{k}_{\mathbf{1}}$ & $\mathbf{R}^{\mathbf{2}}$ & $\mathbf{k}_{\mathbf{H}}$ & $\mathbf{R}^{\mathbf{2}}$ & $\mathbf{k}_{\mathbf{H C}}$ & $\mathbf{R}^{\mathbf{2}}$ & $\mathbf{k}_{\mathbf{P}}$ & $\mathbf{R}^{\mathbf{2}}$ & $\mathbf{n}$ \\
\hline F1 & 17.3 & 0.022 & 0.968 & 0.00 & 0.96 & 0.66 & 0.89 & -0.007 & 0.968 & 0.0042 & 0.905 & 0.534 \\
\hline F2 & 19.9 & 0.029 & 0.8989 & 0.00 & 0.988 & 0.882 & 0.95 & -0.009 & 0.989 & 0.002 & 0.954 & 0.666 \\
\hline F3 & 21.6 & 0.032 & 0.993 & 0.00 & 0.988 & 0.959 & 0.939 & -0.01 & 0.993 & 0.003 & 0.947 & 0.628 \\
\hline F4 & 16.5 & 0.022 & 0.904 & 0.00 & 0.894 & 0.644 & 0.807 & -0.007 & 0.904 & 0.003 & 0.858 & 0.549 \\
\hline F5 & 15.2 & 0.025 & 0.848 & 0.00 & 0.837 & 0.734 & 0.735 & -0.008 & 0.848 & 0.002 & 0.789 & 0.586 \\
\hline F6 & 17.5 & 0.028 & 0.845 & 0.00 & 0.834 & 0.817 & 0.731 & -0.009 & 0.845 & 0.002 & 0.782 & 0.619 \\
\hline F7 & 13.5 & 0.019 & 0.875 & 0.00 & 0.866 & 0.558 & 0.76 & -0.006 & 0.875 & 0.005 & 0.759 & 0.465 \\
\hline F8 & 15.1 & 0.022 & 0.883 & 0.00 & 0.872 & 0.66 & 0.773 & -0.007 & 0.883 & 0.003 & 0.805 & 0.538 \\
\hline F9 & 16.1 & 0.028 & 0.830 & 0.00 & 0.824 & 0.802 & 0.718 & -0.009 & 0.835 & 0.002 & 0.756 & 0.611 \\
\hline
\end{tabular}

${ }^{*} \mathrm{Z}=$ zero, $\mathrm{P}=$ power, $\mathrm{F}=$ first, $\mathrm{H}-\mathrm{C}=$ Hixon Crowell

Table 9. Kinetic studies of $2^{\text {nd }}$ batch

\begin{tabular}{|c|c|c|c|c|c|c|c|c|c|c|c|c|}
\hline & & Z-Or & ler & F-Or & der & H-Mo & & H-C M & del & P- lau & & \\
\hline PRC & $\begin{array}{l}\mathbf{S}_{10 \mathrm{~h}} \\
(\%)\end{array}$ & $\mathbf{k}_{\mathbf{o}}$ & $\mathbf{R}^{2}$ & $\mathbf{k}_{1}$ & $\mathbf{R}^{2}$ & $\mathbf{k}_{\mathbf{H}}$ & $\mathbf{R}^{2}$ & $\mathbf{k}_{\mathrm{HC}}$ & $\mathbf{R}^{2}$ & $\mathbf{k}_{\mathbf{P}}$ & $\mathbf{R}^{2}$ & n \\
\hline F1 & 29.0 & 0.042 & 0.994 & 0.00 & 0.987 & 1.283 & 0.947 & -0.014 & 0.994 & 0.003 & 0.971 & 0.666 \\
\hline $\mathrm{F} 2$ & 32.8 & 0.046 & 0.992 & 0.00 & 0.984 & 1.414 & 0.954 & -0.015 & 0.992 & 0.004 & 0.977 & 0.657 \\
\hline F3 & 35.4 & 0.051 & 0.9965 & 0.00 & 0.99 & 1.542 & 0.963 & -0.017 & 0.996 & 0.004 & 0.984 & 0.653 \\
\hline F4 & 26.2 & 0.038 & 0.994 & 0.00 & 0.996 & 1.181 & 0.981 & -0.012 & 0.994 & 0.004 & 0.992 & 0.637 \\
\hline F5 & 28.0 & 0.038 & 0.995 & 0.00 & 0.996 & 1.184 & 0.979 & -0.012 & 0.995 & 0.006 & 0.987 & 0.574 \\
\hline F6 & 31.2 & 0.043 & 0.998 & 0.00 & 0.996 & 1.316 & 0.965 & -0.014 & 0.998 & 0.008 & 0.965 & 0.549 \\
\hline F7 & 24.7 & 0.035 & 0.988 & 0.00 & 0.987 & 1.077 & 0.954 & -0.01 & 0.988 & 0.006 & 0.961 & 0.555 \\
\hline F8 & 27.2 & 0.035 & 0.993 & 0.00 & 0.997 & 1.101 & 0.989 & -0.012 & 0.993 & 0.011 & 0.988 & 0.492 \\
\hline F9 & 31.1 & 0.04 & 0.995 & 0.00 & 0.996 & 1.224 & 0.982 & -0.013 & 0.995 & 0.013 & 0.977 & 0.479 \\
\hline
\end{tabular}

Table 10. Kinetic studies of $3^{\text {rd }}$ batch

\begin{tabular}{|l|l|l|l|l|l|l|l|l|l|l|l|l|l|}
\hline & \multicolumn{3}{|l|}{ Z- Order } & \multicolumn{2}{l|}{ F-Order } & \multicolumn{2}{l|}{ H-Model } & \multicolumn{3}{l|}{ H-C Model } & \multicolumn{3}{l|}{ P- law } \\
\hline PRC & $\mathbf{S}_{\mathbf{1 0 h}(\%)}$ & $\mathbf{k}_{\mathbf{o}}$ & $\mathbf{R}^{\mathbf{2}}$ & $\mathbf{k}_{\mathbf{1}}$ & $\mathbf{R}^{\mathbf{2}}$ & PRC & $\mathbf{S}_{\mathbf{1 0 h}(\%)}$ & $\mathbf{k}_{\mathbf{o}}$ & $\mathbf{R}^{\mathbf{2}}$ & $\mathbf{k}_{\mathbf{1}}$ & $\mathbf{R}^{\mathbf{2}}$ & PRC \\
\hline F1 & 25.1 & 0.038 & 0.988 & 0.001 & 0.999 & 1.155 & 0.946 & -0.012 & 0.985 & 0.003 & 0.966 & 0.632 \\
\hline F2 & 26.7 & 0.041 & 0.985 & 0.001 & 0.985 & 1.236 & 0.985 & -0.013 & 0.987 & 0.005 & 0.987 & 0.621 \\
\hline F3 & 27.9 & 0.043 & 0.986 & 0.001 & 0.983 & 1.244 & 0.996 & -0.013 & 0.981 & 0.004 & 0.994 & 0.595 \\
\hline F4 & 21.8 & 0.038 & 0.946 & 0.001 & 0.964 & 1.186 & 0.977 & -0.012 & 0.943 & 0.003 & 0.975 & 0.654 \\
\hline F5 & 24.6 & 0.038 & 0.984 & 0.001 & 0.997 & 1.213 & 0.972 & -0.013 & 0.982 & 0.004 & 0.976 & 0.663 \\
\hline F6 & 26.0 & 0.036 & 0.957 & 0.001 & 0.974 & 1.174 & 0.985 & -0.012 & 0.951 & 0.005 & 0.994 & 0.582 \\
\hline F7 & 23.5 & 0.037 & 0.933 & 0.001 & 0.956 & 1.119 & 0.986 & -0.01 & 0.932 & 0.005 & 0.993 & 0.573 \\
\hline F8 & 24.0 & 0.039 & 0.978 & 0.001 & 0.994 & 1.198 & 0.985 & -0.012 & 0.976 & 0.006 & 0.988 & 0.536 \\
\hline F9 & 25.6 & 0.037 & 0.994 & 0.001 & 0.997 & 1.113 & 0.987 & -0.012 & 0.991 & 0.014 & 0.977 & 0.462 \\
\hline
\end{tabular}


Table 11. Kinetic studies of $4^{\text {th }}$ batch

\begin{tabular}{|c|c|c|c|c|c|c|c|c|c|c|c|c|}
\hline & \multicolumn{2}{|c|}{ Z- Order } & \multicolumn{2}{|c|}{ F-Order } & \multicolumn{2}{|c|}{ H-Model } & \multicolumn{2}{|c|}{ H-C Model } & \multicolumn{3}{|c|}{ P- law } \\
\hline PRC & $\mathbf{S}_{10 h(\%)}$ & $\mathbf{k}_{\mathbf{o}}$ & $\mathbf{R}^{2}$ & $\mathbf{k}_{1}$ & $\mathbf{R}^{2}$ & $\mathbf{k}_{\mathbf{H}}$ & $\mathbf{R}^{2}$ & kHC & $\mathbf{R}^{2}$ & $\mathbf{k P}$ & $\mathbf{R}^{2}$ & $\mathbf{n}$ \\
\hline F1 & 31.5 & 0.046 & 0.994 & 0.001 & 0.985 & 1.422 & 0.951 & -0.014 & 0.994 & 0.004 & 0.976 & 0.631 \\
\hline $\mathrm{F} 2$ & 37.2 & 0.052 & 0.993 & 0.001 & 0.988 & 1.564 & 0.957 & -0.016 & 0.994 & 0.004 & 0.981 & 0.635 \\
\hline F3 & 43.3 & 0.063 & 0.994 & 0.001 & 0.971 & 1.866 & 0.933 & -0.022 & 0.992 & 0.006 & 0.964 & 0.656 \\
\hline $\mathrm{F} 4$ & 30.4 & 0.038 & 0.992 & 0.001 & 0.994 & 1.214 & 0.973 & -0.012 & 0.995 & 0.005 & 0.9 & 0.584 \\
\hline F5 & 35.6 & 0.045 & 0.999 & 0.001 & & 1.332 & 0.962 & & 0.997 & 0.008 & 0.962 & 0.536 \\
\hline F6 & 37.5 & 0.044 & 0.997 & 0.001 & 0.992 & 1.406 & 0.962 & -0.014 & 0.995 & 0.012 & 0.951 & 0.511 \\
\hline F7 & 28.2 & 0.039 & 0.995 & 0.001 & 0.997 & 1.165 & 0.986 & -0.013 & 0.993 & 0.009 & 0.992 & 0.528 \\
\hline F8 & 31.9 & 0.043 & 0.993 & 0.001 & 0.991 & 1.227 & 0.972 & -0.014 & 0.992 & 0.014 & 0.968 & 0.477 \\
\hline F9 & 34.8 & 0.044 & 0.996 & 0.001 & 0.988 & 1.357 & 0.957 & -0.016 & 0.996 & 0.013 & 0.963 & 0.482 \\
\hline
\end{tabular}

Similarity and difference factors

The DR profile of all formulations was compared with sustained release marketed tablet and their similarity factors were found to be $>50$. From these values (Table 12) it was found that their DR mechanism was

Table 12. Similarity and difference factors

\begin{tabular}{|l|l|l|l|l|l|l|l|l|l|l|}
\hline \multicolumn{2}{l|}{ PRC } & F1 & F2 & F3 & F4 & F5 & F6 & F7 & F8 & F9 \\
\hline \multirow{2}{*}{ st $^{\text {batch }}$} & f1 & 66.58 & 69.67 & 72.36 & 70.25 & 73.24 & 75.95 & 73.44 & 74.96 & 76.61 \\
\cline { 2 - 11 } & f2 & 67.17 & 73.59 & 77.04 & 65.14 & 65.15 & 65.26 & 57.90 & 60.41 & 62.57 \\
\hline \multirow{2}{*}{ Cstd } & f1 & 61.23 & 64.80 & 67.95 & 65.49 & 68.97 & 72.10 & 69.19 & 70.95 & 72.85 \\
\cline { 2 - 11 } & f2 & 50.31 & 55.45 & 58.82 & 49.21 & 49.30 & 49.56 & 45.11 & 46.67 & 47.99 \\
\hline \multirow{2}{*}{$2^{\text {nd }}$ batch } & f1 & 39.98 & 48.74 & 56.64 & 65.14 & 67.39 & 70.04 & 68.75 & 72.34 & 74.63 \\
\cline { 2 - 11 } & f2 & 59.64 & 53.91 & 49.45 & 61.62 & 58.74 & 53.28 & 64.17 & 57.32 & 51.70 \\
\hline \multirow{2}{*}{ Cstd } & f1 & 30.36 & 40.52 & 49.69 & 59.55 & 62.17 & 65.24 & 63.74 & 67.91 & 70.56 \\
\cline { 2 - 11 } & f2 & 76.55 & 85.88 & 78.49 & 73.12 & 79.71 & 85.61 & 70.27 & 79.40 & 78.99 \\
\hline \multirow{3}{*}{${ }^{\text {rd }}$ batch } & f1 & 14.58 & 20.85 & 26.48 & 26.45 & 29.60 & 41.31 & 23.73 & 32.11 & 36.30 \\
\cline { 2 - 11 } & f2 & 71.69 & 63.46 & 60.40 & 77.58 & 72.34 & 67.50 & 76.11 & 71.82 & 66.83 \\
\hline \multirow{2}{*}{ Cstd } & f1 & 10.49 & 12.51 & 15.06 & 14.83 & 18.32 & 31.91 & 11.87 & 21.23 & 26.09 \\
\cline { 2 - 10 } & f2 & 67.56 & 76.32 & 78.50 & 61.63 & 68.58 & 73.09 & 63.34 & 68.81 & 70.87 \\
\hline \multirow{2}{*}{${ }^{\text {th }}$ batch } & f1 & 10.03 & 20.84 & 31.55 & 22.77 & 30.32 & 36.06 & 38.81 & 42.25 & 45.76 \\
\cline { 2 - 10 } & f2 & 53.86 & 49.00 & 43.26 & 57.29 & 50.94 & 47.50 & 60.46 & 55.67 & 48.79 \\
\hline \multirow{2}{*}{ Cstd } & f1 & 11.20 & 9.95 & 20.58 & 11.88 & 19.15 & 25.81 & 29.00 & 32.99 & 37.07 \\
\cline { 2 - 9 } & f2 & 85.66 & 79.51 & 62.77 & 81.42 & 85.37 & 73.77 & 77.07 & 92.10 & 76.49 \\
\hline
\end{tabular}

\section{Regression analysis}

The regression analysis was conducted to find the effect of variables on drug release rate. The negative sign of factors in equation indicates that its amount should be decreased while positive sign indicates that
non-Fickian diffusion. The value of difference factor for no difference lie inbetween $0-15$ but most of the formulations deviated from this range showing that their release pattern is anomalous and need to explore further. 


\section{i) $1^{\text {st }}$ Batch}

2h study

$\mathrm{S}_{12 \mathrm{~h}}=0.0137 \mathrm{t}+0.013 \mathrm{~A}-0.043 \mathrm{~B}-7 \mathrm{E}^{-05} \mathrm{AB}+7.1 \mathrm{E}^{-05} \mathrm{~A}^{2}+0.0008 \mathrm{~B}^{2}+2.82$

$\left(\mathrm{CRC}=0.913, \mathrm{R}^{2}=0.83, \operatorname{Adj} \cdot \mathrm{R}^{2}=0.785, \mathrm{n}=27\right)$

5 h study

S1 $5 \mathbf{h}=0.016 \mathrm{t}-0.031 \mathrm{~A}+0.1005 \mathrm{~B}-0.0004 \mathrm{AB}+6.07^{\mathrm{E}-05} \mathrm{~A}^{2}-0.0003 \mathrm{~B}^{2}+4.79(\mathrm{CRC}=0.922$, $\mathrm{R}^{2}=0.8511$, Adj. $\mathrm{R}^{2}=0.8311, \mathrm{n}=54$ )

10h study

$\mathrm{S} 11_{10 \mathrm{~h}}=0.0231 \mathrm{t}-0.0622 \mathrm{~A}+0.2501 \mathrm{~B}-0.0007 \mathrm{AB}+0.0001 \mathrm{~A}^{2}-0.0015 \mathrm{~B}^{2}+5.085$

$\left(\mathrm{CRC}=0.9611, \mathrm{R}^{2}=0.9262\right.$, Adj. $\left.\mathrm{R}^{2}=0.9213, \mathrm{n}=99\right)($ Figure 8$)$.
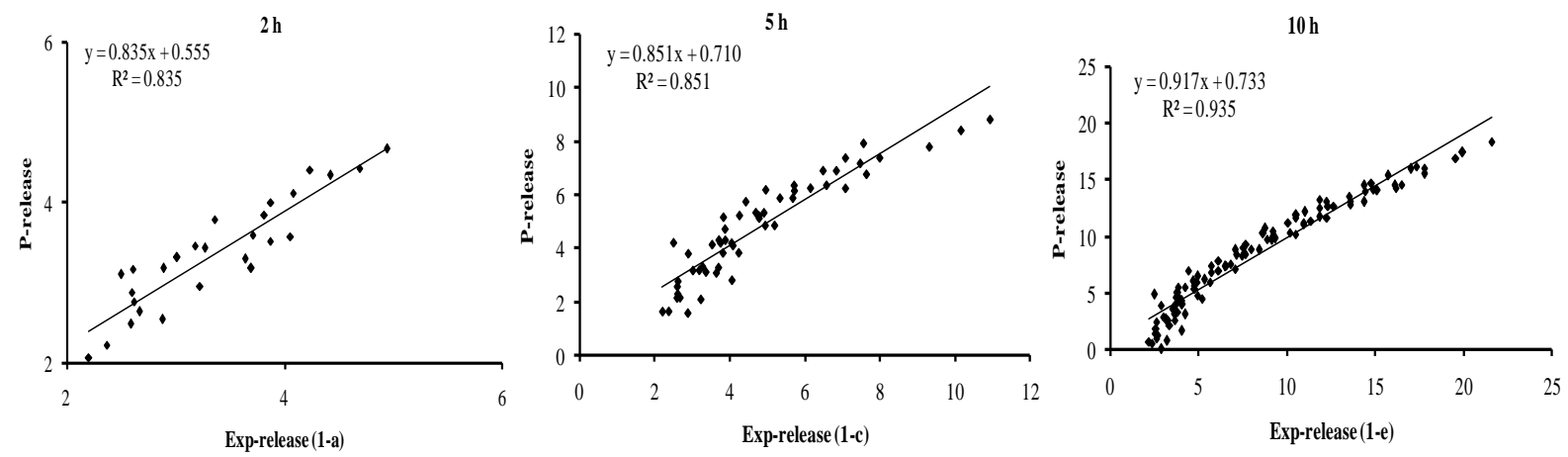

Figure 8. The Scattered plot for $1^{\text {st }}$ batch is shown in Figure $1(a, c$ and e).

ii) $2^{\text {nd }}$ Batch

$\mathrm{S} 22_{\mathrm{h}}=0.046 \mathrm{t}-0.0391 \mathrm{~A}+0.0556 \mathrm{~B}+0.00034 \mathrm{AB}+0.000167 \mathrm{~A}^{2}-0.00056 \mathrm{~B}^{2}+3.349$

$\left(\mathrm{CRC}=0.97231, \mathrm{R}^{2}=0.94611 \mathrm{Adj} . \mathrm{R}^{2}=0.93022, \mathrm{n}=27\right)$

5 h study

$\mathrm{S} 25 \mathbf{h}=0.041 \mathrm{t}-0.041 \mathrm{~A}+0.118 \mathrm{~B}+0.0008 \mathrm{AB}+0.0001 \mathrm{~A}^{2}+0.0096 \mathrm{~B}^{2}+2.853\left(\mathrm{CRC}=0.987, \mathrm{R}^{2}=\right.$ 0.974 , Adj. $\mathrm{R}^{2}=0.971, \mathrm{n}=54$ )

10h study

$\mathrm{S} 210 \mathrm{~h}=0.0411 \mathrm{t}-0.0651 \mathrm{~A}+0.09 \mathrm{~B}+0.0001 \mathrm{AB}+0.0002 \mathrm{~A}^{2}+5.2^{\mathrm{E}-05} \mathrm{~B}^{2}+5.039$

$\left(\mathrm{CRC}=0.995, \mathrm{R} 2=0.980, \mathrm{Adj}_{\mathrm{R}} \mathrm{R}^{2}=0.979, \mathrm{n}=99\right)($ Figure 9$)$.
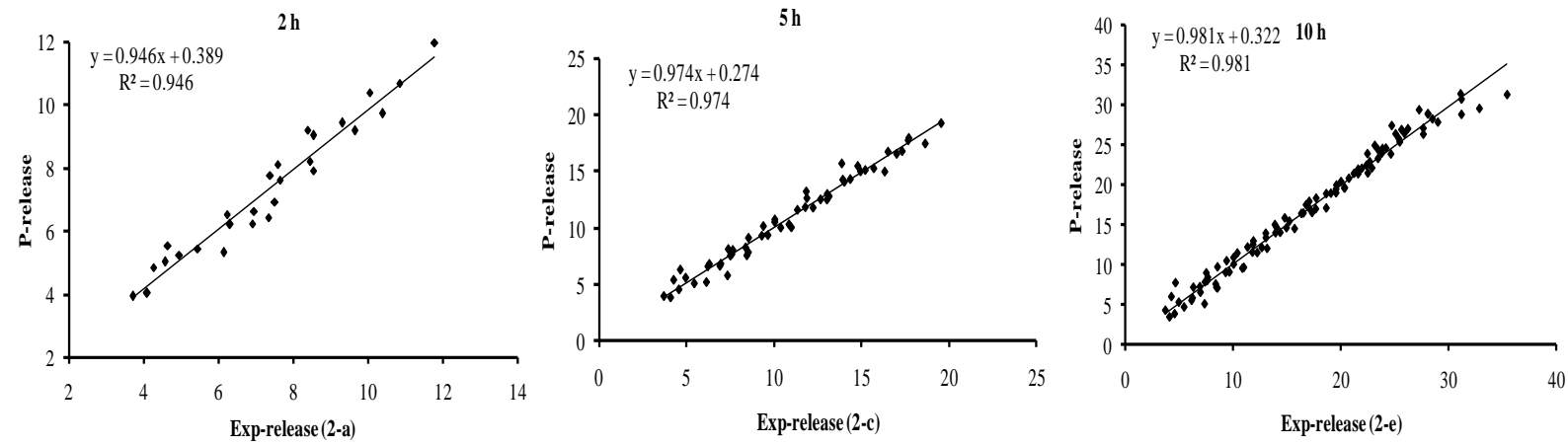

Figure 9. Scattered plot between experimental and predicted release figure $2(\mathrm{a}, \mathrm{c}$ and $\mathrm{e})$. 


\section{iii) $3^{\text {rd }}$ batch}

2h study

$\mathrm{S} 3 \mathbf{2}_{\mathrm{h}}=0.0463 \mathrm{t}-0.03 \mathrm{~A}+0.266 \mathrm{~B}-0.004 \mathrm{AB}+0.0003 \mathrm{~A}^{2}-0.002 \mathrm{~B}^{2}+2.27$

$\left(\mathrm{CRC}=0.941, \mathrm{R}^{2}=0.908, \quad\right.$ Adj. $\left.\mathrm{R}^{2}=0.877, \mathrm{n}=27\right)$

5 h study

$\mathrm{S} 3 \mathbf{5 h}=0.0397 \mathrm{t}-0.09 \mathrm{~A}+0.334 \mathrm{~B}-0.007 \mathrm{AB}+0.0003 \mathrm{~A}^{2}-0.002 \mathrm{~B}^{2}+5.6724$

$\left(\mathrm{CRC}=0.989, \mathrm{R}^{2}=0.9696\right.$, Adj. $\left.\mathrm{R}^{2}=0.9578, \mathrm{n}=54\right)$

10h study

S3 $10 \mathrm{~h}=0.0363 \mathrm{t}-0.1360 \mathrm{~A}+0.3875 \mathrm{~B}-0.0005 \mathrm{AB}+0.0004 \mathrm{~A}^{2}-0.0037 \mathrm{~B}^{2}+9.1875$

$\left(\mathrm{CRC}=0.9919, \mathrm{R}^{2}=0.9839\right.$, Adj. $\left.\mathrm{R}^{2}=0.9827, \mathrm{n}=99\right)($ Figure 10).
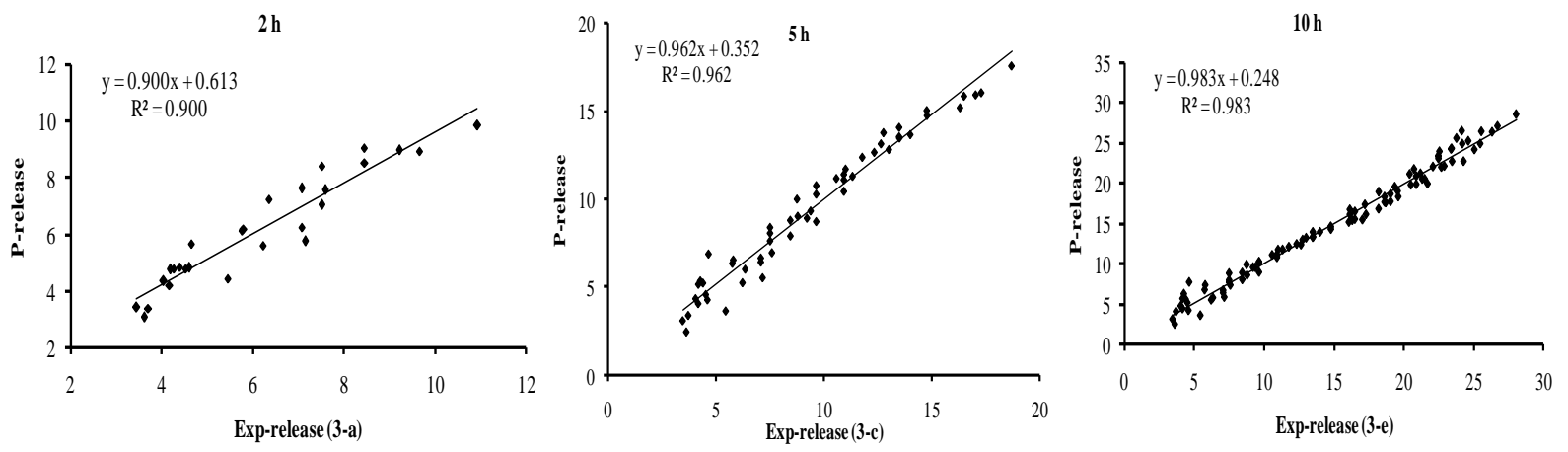

Figure 10. Scattered plot between experimental release and predicted release figure 3(a, $\mathrm{c}$ and e)

\section{iv) $4^{\text {th }}$ batch}

$2 \mathrm{~h}$ study

$\mathrm{S} 4 \mathbf{2} \mathbf{h}=0.043 \mathrm{t}-0.047 \mathrm{~A}+0.333 \mathrm{~B}-0.0001 \mathrm{AB}+0.0001 \mathrm{~A}^{2}-0.004 \mathrm{~B}^{2}+3.375\left(\mathrm{CRC}=0.8811, \mathrm{R}^{2}\right.$ $=0.7832, \operatorname{Adj} . \mathrm{R}^{2}=0.7182, \mathrm{n}=27$ )

5 h study

$\mathrm{S} 4 \mathbf{5} \mathbf{h}=0.0421 \mathrm{t}-0.096 \mathrm{~A}+0.423 \mathrm{~B}+6.6 \mathrm{E}-05 \mathrm{AB}+0.000277 \mathrm{~A}^{2}-0.006 \mathrm{~B}^{2}+5.738(\mathrm{CRC}=0.96$, $\mathrm{R} 2=0.9194$, Adj. $\mathrm{R}^{2}=0.984, \mathrm{n}=54$ )

10h study

$\mathrm{S} 4{ }_{10} \mathrm{~h}=-0.0068 \mathrm{~A}+1.598 \mathrm{~B}-0.001 \mathrm{AB}-9^{\mathrm{E}-06} \mathrm{~A}^{2}-0.013 \mathrm{~B}^{2}+15.063$

$\left(\mathrm{CRC}=0.77621, \mathrm{R}^{2}=0.592, \mathrm{Adj} \cdot \mathrm{R}^{2}=-0.0833, \mathrm{n}=9\right)($ Figure 11).
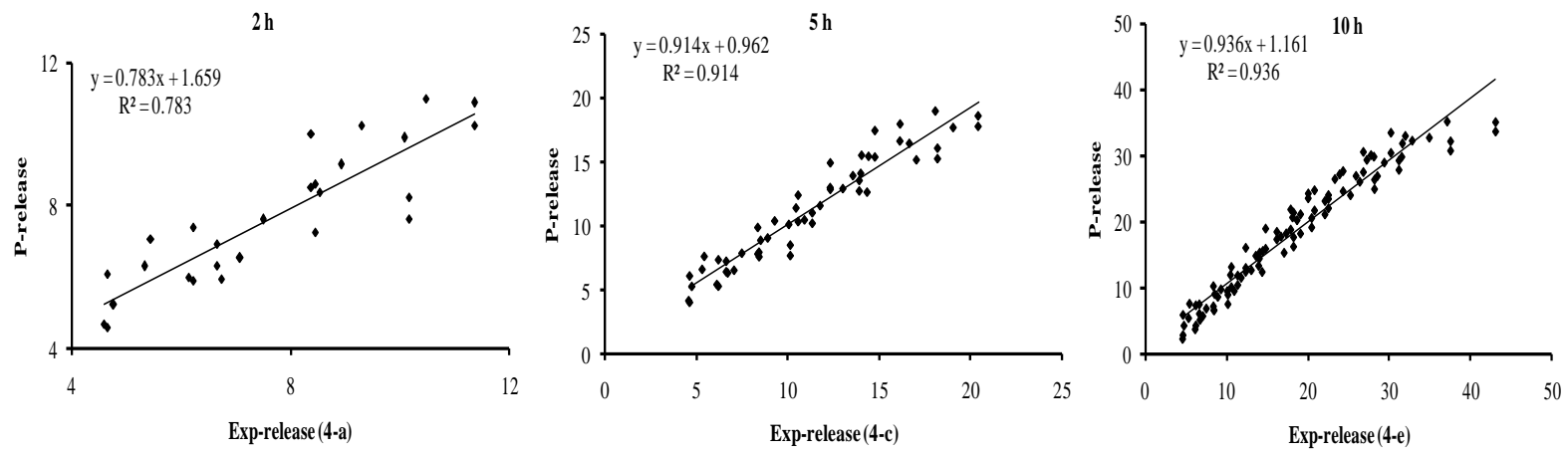

Figure 11. Scattered plot between experimental and predicted release for $4^{\text {th }}$ batch 
The all given plots indicate best correlation between theoretical and experimental drug release profiles.

Table 13. Effect of all variables on DR profiles of formulations of all batches at different time intervals

\begin{tabular}{|c|c|}
\hline \multicolumn{2}{|l|}{ 1 $^{\text {st }}$ batch } \\
\hline 2 h study & $\mathrm{B}(2.205)>\mathrm{A}^{2}(0.024)>\mathrm{AB}(0.023)>\mathrm{A}(0.021)>\mathrm{B}^{2}(0.006)$ \\
\hline 5 h study & $\mathrm{A}(0.358)>\mathrm{AB}(0.238)>\mathrm{B}(0.230)>\mathrm{A}^{2}(0.208)>\mathrm{B}^{2}(0.033)$ \\
\hline 10h study & $\mathrm{A}(0.327)>\mathrm{B}(0.263)>\mathrm{A}^{2}(0.233)>\mathrm{AB}(0.203)>\mathrm{B}^{2}(0.064)$ \\
\hline \multicolumn{2}{|l|}{$2^{\text {nd }}$ batch } \\
\hline 2 h study & $\mathrm{B}(3.727)>\mathrm{AB}(0.096)>\mathrm{A}(0.054)>\mathrm{A}^{2}(0.046)>\mathrm{B}^{2}(0.008)$ \\
\hline 5 h study & $\mathrm{A}(0.261)>\mathrm{A}^{2}(0.259)>\mathrm{B}(0.224)>\mathrm{AB}(0.1749)>\mathrm{B}^{2}(0.13)$ \\
\hline 10h study & $\mathrm{A}(0.215)>\mathrm{A}^{2}(0.193)>\mathrm{B}(0.093)>\mathrm{AB}(0.037)>\mathrm{B}^{2}(0.002)$ \\
\hline \multicolumn{2}{|l|}{$3^{\text {rd }}$ batch } \\
\hline 2 h study & $\mathrm{B}(13.67)>\mathrm{AB}(0.157)>\mathrm{A}(0.057)>\mathrm{A}^{2}(0.0463)>\mathrm{B}^{2}(0.02)$ \\
\hline 5 h study & $\mathrm{A}^{2}(0.619)>\mathrm{A}(0.59)>\mathrm{B}(0.437)>\mathrm{AB}(0.232)>\mathrm{B}^{2}(0.1154)$ \\
\hline 10h study & $\mathrm{A}(0.552)>\mathrm{A}^{2}(0.535)>\mathrm{B}(0.314)>\mathrm{B}^{2}(0.120)>\mathrm{AB}(0.111)$ \\
\hline \multicolumn{2}{|l|}{$4^{\text {th }}$ batch } \\
\hline 2 h study & $\mathrm{B}(25.997)>\mathrm{A}(0.076)>\mathrm{B}^{2}(0.076)>\mathrm{A}^{2}(0.050)>\mathrm{AB}(0.04)$ \\
\hline 5 h study & $\mathrm{B}(0.799)>\mathrm{B}^{2}(0.687)>\mathrm{A}(0.601)>\mathrm{A}^{2}(0.524)>\mathrm{AB}(0.031)$ \\
\hline 10h study & $\mathrm{B}(3.20)>\mathrm{B}^{2}(2.336)>\mathrm{AB}(0.776)>\mathrm{A}(0.045)>\mathrm{A}^{2}(0.018)$ \\
\hline
\end{tabular}

\section{Conclusions}

All fractions are polysaccharides in nature and due to having swelling, reswelling properties these can be used for designing the sustained release formulations and due to low density they can float over the surface of dissolution medium and hence are suitable for gastro retentive drug release tablets/floats. The Plantago Ovata husk gel has many pharmaceutical properties and is successfully used in diseases like constipation, hyperglycemia and coronary heart diseases. Due to being herbal medicine, they can be successfully applied for designing the controlled release floats. The full factorial design $3^{2}$ reveals that all independent variables shows significant effect on DR rate, lag time and floating time of floats. The SRA (standard regression analysis) shows that the $A$ and $B$ are basic parameters and their alteration can be helpful to achieve the desired DR profile. The positive and negative signs in regression analysis indicates that the value of that variable must be decreased or increased to get required DR profile. Similarity and difference factor is helpful in finding the resemblance or difference with standard DR profile. The thermal study indicates that $\mathrm{ENa}$ is thermally stable can withstand environmental changes. The GPC study of these fractions revealed that their PDI values are changing from 2 to 3.74 showing that polymers are poly disperse in nature. All excipients used were herbal in nature and biocompatible to body and are included in GRAS list. Due to these exceptional properties, we can conclude that these fractions are totally safe to use as matrix formation in CDDS, and also have a potential as food preservative films [25]. The values of $\mathrm{R}^{2}$ from kinetic study and $\mathrm{RA}$ are helpful in interpreting the nature of matrix. In the last formulation, the value of $\mathrm{R}^{2}$ for power law 0.965 with $\mathrm{n}$ value $\approx 0.482$ indicates best fit to required release 
mechanism. So this formulation was considered to be optimized formulation. Same values or even better values for $\mathrm{R}^{2}$ are also seen in some other formulations but their DR rates or mechanism are not best fitted to targeted criteria (swelling/diffusion).

\section{Authors' contributions}

Conceived and designed the experiments: A Karim, Performed the experiments: A Karim, Analysis of data: A Karim, Contributed reagents /materials/ analysis tools: $\mathrm{T}$ Mehmood, Wrote the paper: A Karim \& MA Shaheen.

\section{References}

1. Beneke EC, Viljoen AM \& Hamman JH (2009). Plant derived excipients in drug delivery. Molecules 14: 2602.

2. Sivabalan M, Punitha Vani T, Anup J \& Nigila G (2011).J. Pharmacie Globale, Int. J Comprehensive Pharmacy 02: 01.

3. Lalwani AN \& Parikh JR (2008). Preparation and evaluation of an Ispaghula based directly compressible matrixing agent for controlled release. Acta Pharm 58: 309.

4. Saboji JK, Gadve RB \& Patil SM (2012). Development of Oral Colon Specific $\mathrm{pH}$ Dependent Microcapsules of NSAID Drug Naproxen. J Applied Pharma Sci 02 (05): 202.

5. Iqbal MS, Akbar J, Hussain MA, Saghir S \& Sher M (2011). Evaluation of hotwater extracted arabinoxylans from ispaghula seeds as drug carriers. Carbohydr polym 83 (3): 1218.

6. Monica RPR, Deepa U, Warrier \& ShivaniRaoH (2015). Evaluation of Phosphorylated Psyllium Seed Polysaccharide as a Release Retardant. Indian J Pharm Sci 77(5): 605.

7. Iqbal MS, Akbar J, Saghir S, Karim A \& Koschella A (2011). Thermal studies of plant carbohydrate polymer hydrogels. Carbohydr Polym 86(4): 1775.
8. Gupta GD \& Gaud RS (2000). Formulation and Evaluation of Dispersible Tablets Using Natural Disintegrants. Ind J Pham Sci 62(5): 339.

9. Kirtikar KK \& Basu BD (1980). Indian Medicinal Plants. 2nd ed. M.B.Lalith, 2: 110.

10. Martindale-The Extra Pharmacopoeia, 31st ed. (1996). The Royal Pharmaceutical Society 80.

11. Ravi Kiran N, Palanichamy S, Rajesh M, Godwin Rajadhas T, Anusha V, Parasakthi N \& Thanga Thirupathi A (2010). Formulation and Evaluation of Orodispersible piroxicam Tablets. Pharm Sci \& Res 2(10): 615.

12. Costa $P$ (2001). An alternative method to the evaluation of similarity factor in dissolution testing. Int J Pharm. 220: 77.

13. Korsmeyer RW, Gurny R, Doelker EM, Buri P \& NA Peppas (1983). Mechanism of solute release from porous hydrophilic polymers. Int. $\mathbf{J}$ Pharm 15: 25-35.

14. Cartensen JT (1996). Modeling and data treatment in the pharmaceutical sciences, Ed., Technomic Publishing Co. Inc., New York, Basel.

15. Mauger JW, Chilko D \& Howard S (1986). On the analysis of the dissolution data. Drug Dev Ind Pharm 12: 969-92

16.Polli JE ${ }^{1}$, Rekhi GS, Augsburger LL, Shah VP (1997). Methods to compare dissolution profiles and a rationale for wide dissolution specifications for metoprolol tartrate tablets. J Pharm Sci 86(6): 690-700.

17. Moore JW \& Flanner HH (1996). Mathematical comparison of dissolution profiles. Pharma Tech 20(6): 64.

18. Fischer HM, Nanxiong Y, Gary Y, Gray, John R, Laurensand A \& Judith AM (2004). The gel-forming polysaccharide 
of psyllium husk (Plantago Ovata Forsk). Carbohydr Res 339: 2009.

19. Saghir S, Iqbal MS, Koschella A \& Heinze $T$ (2009). Ethylation of arabinoxylan from Ispaghula (Plantago ovata) seed husk. Carbohydr Polym 77 (1): 125

20. Madani M (2011). Structure, optical and thermal decomposition characters of LDPE graft copolymers synthesized by gamma irradiation. Current Applied Physics 11(1): 70.

21. Adel AM, Abd ZH, El-Wahab, Ibrahim AA \& Al-Shemy MT (2010). Characterization of microcrystalline cellulose prepared from lignocellulosic materials. Part Acid catalyzed hydrolysis. Biores Tech 101(12): 4446.

22. Ghaemy M \& Amini Nasab SM (2010). Synthesis and identification of organosoluble polyamides bearing a triaryl imidazole pendent: Thermal, photophysical, chemiluminescent, and electrochemical characterization with a modified carbon nanotube electrode. Reactive Functional Poly 70(5): 306.

23. Mallakpour S \& Dinari M (2010). Ecofriendly fast synthesis and thermal degradation of optically active polyamides under microwave accelerating conditions, Chinese Journal of Polymer Science 28(5): 685.

24. Iqbal SM, Shazma M, Jamshed A \& Rashid Chaudhary MA (2013).Thermal analysis of some natural polysaccharide materials by isoconversional method. Food Chem 140:178.

25. Ahmadi R, Kalbasi A, Oromiehie, Yarmand \& Jahandideh (2012). Development and characterization of a novel biodegradable edible film obtained from psyllium seed (Plantago ovate Forsk) J Food Eng 109: 745. 